\title{
Glyceryl trinitrate patch versus intravenous ritodrine for tocolysis in pre-term labour
}

\author{
Charu Jain*, Maruti Sinha, Rekha Rani, Aruna Tiwari
}

Department of Obstetrics and Gynaecology, Kasturba Hospital, Darya Ganj, New Delhi - 110002, India

Received: 12 October 2016

Accepted: 07 November 2016

\section{*Correspondence:}

Dr. Charu Jain,

E-mail: maruti_2203@yahoo.com

Copyright: $\odot$ the author(s), publisher and licensee Medip Academy. This is an open-access article distributed under the terms of the Creative Commons Attribution Non-Commercial License, which permits unrestricted non-commercial use, distribution, and reproduction in any medium, provided the original work is properly cited.

\begin{abstract}
Background: Preterm birth is the single most important determinant of adverse infant outcome. Tocolytic therapy has shown beneficial effect in certain selected patients. The present study was conducted to evaluate the efficacy, maternal and fetal outcome with the use of Transdermal Glyceryl nitrate patches versus Intravenous Ritodrine tocolytic agents.

Methods: Study included 50 patients of gestation 24-34 weeks in preterm labor. Group I: Glyceryl trinitrate patch releasing $10 \mathrm{mg} / 24$ hours $(0.4 \mathrm{mg} /$ hour $)$ was applied transdermally and repeated after 2 hours if no reduction in contractions was seen. Group II: Intravenous Ritodrine infusion prepared by adding $50 \mathrm{mg}$ to a bottle of $5 \%$ dextrose or ringer lactate solution and infusion started at an initial rate of $0.05 \mathrm{mg} / \mathrm{min}$ which was increased by 50 micrograms per minute every 15 min until contractions ceased.

Results: 22 patients in group I treated with GTN and 19 patients in group II treated with Ritodrine achieved successful tocolysis. The difference was statistically insignificant (P value - 0.23). Mean Gestational age at delivery was 34.97 in GTN Group as compared to 33.24 weeks in Ritodrine Group ; difference which is statistically significant $(\mathrm{P}=0.0004)$. Very few adverse effects were observed in the GTN Group. Comparatively, the Ritodrine Group had severe adverse effects requiring discontinuation of therapy. Fetal outcome was satisfactory in both groups.

Conclusions: The effects of Glyceryl trinitrate and Ritodrine in the treatment of preterm labor were essentially similar. Glyceryl trinitrate is associated with lesser maternal and fetal adverse effects and appears to be a very viable, inexpensive and safer alternative to Ritodrine.
\end{abstract}

Keywords: GTN Patch, IV Ritodrine, Preterm labour, Tocolysis

\section{INTRODUCTION}

Preterm birth, is the single most important determinant of adverse infant outcome in terms of both survival and quality of life and is defined as birth at less than 37 weeks of gestation after attaining neonatal viability of 20-28 weeks. ${ }^{1,2}$ The overall incidence is $6-15 \%, 3$ accounting for nearly $75 \%$ of perinatal deaths in developing countries. ${ }^{5}$ There is growing recognition of increased risk of infant mortality in moderate preterm birth between 32 to 37 weeks. ${ }^{6,7}$
Preterm delivery remains a major public health problem in terms of loss of life, long term disability like cerebral palsy, blindness, deafness, chronic lung disease and developmental delay. Decreasing gestation age increases risk of neurosensory disability and death. A premature infant has huge psychosocial and emotional effects on the family. ${ }^{1,8,9}$

Preterm Labour is characterized by observable uterine contractions of at least one every 10 minutes of sufficient magnitude to effect progressive cervical dilatation up to $2 \mathrm{~cm}$, cervical length less than $1 \mathrm{~cm}$ or rupture of 
membranes. ${ }^{2,8,10}$ Intervention with tocolytics remain a dilemma, due to non-availability of a wide spectrum of pharmacological agents. Existing drugs have relatively short duration of action, lack utero-specificity, have poor efficacy and are often associated with potentially serious maternal and fetal adverse effects. ${ }^{11}$ Tocolytics delay PTL long enough for corticosteroids to induce fetal lung maturation or allow mother's transportation to a tertiary care centre but they have not been shown to greatly improve neonatal outcomes. $^{12,13}$

Ritodrine hydrochloride, a $\beta$-adrenergic stimulant is the first drug approved by the FDA for the pharmacological inhibition of preterm labour. ${ }^{14} \beta 2$ adrenergic receptors in uterine wall relaxes uterine smooth muscle, however, $\alpha 1$, $\alpha 2$ receptors are also stimulated by beta mimetics thereby causing serious maternal side effects like pulmonary edema, myocardial ischemia, arrhythmia, death. ${ }^{15}$

The Beta sympathomimetic like Ritodrine, Salbutamol, Terbutaline) have largely been replaced by other drugs such as Calcium Channel Blockers (King 2002), Prostalandin Synthetase Inhibitors COX 2 (King 2005), Nitrous Oxide Donors (Yallanpalli 1993, 1994) due to potentially serious maternal adverse effects. ${ }^{16} \mathrm{NO}$ produced endogenously by many cells is a highly reactive signalling molecule which lowers intracellular ionized calcium and causes smooth muscle relaxation by increasing GMP. NO is a very unstable molecule that is inactivated by superoxide free radicals and hence has a very short term effect. ${ }^{17}$ Nitroglycerine Transdermal Patches for PTL management has shown comparable results and there is a need for further critical evaluation by well-planned and well monitored studies.

The aim of this study is to evaluate the therapeutic response of Transdermal Glyceryltrinitrate Patches as a tocolytic to prevent pre term delivery and to compare the efficacy, maternal and fetal adverse effects and neonatal outcome with the traditionally used intravenous Ritodrine.

\section{METHODS}

The trial was conducted in Kasturba Hospital, Department of Obstetrics and Gynaecology. Recruitment of fifty patients was done depending upon gestation age of between 24 weeks to 34 weeks and those having painful uterine contractions at regular intervals of more than one in every 10 minutes for over an hour with less than $3 \mathrm{~cm}$ cervical dilatation, less than $80 \%$ cervical effacement and intact membranes.

Excluded from the study were those patients who had any contraindication to prolongation of pregnancy by tocolysis namely unsatisfactory fetal cardiotocography, antepartum haemorrhage, placenta praevia, chorioamnionitis features, premature rupture of membranes or cervical dilatation more than $3 \mathrm{cms}$. Patients with medical illness, sensitivity or contraindication to either of the drugs GTN or Ritodrine were also excluded from the study.

Randomized treatment with Transdermal Glyceryl Trinitrate Patch or Intravenous Beta Mimetic Ritodrine was initiated and assigned Group I and Group II accordingly.

\section{Methodology}

On admission of a patient in preterm labour, details of her medical history, present and past obstetric history was meticulously recorded. General physical examination and detailed obstetric examination per abdomen and per vaginum was performed. The selected patients were randomized either to Group $\mathrm{I}$ if treated with Glyceryltrinitrate (GTN) patch or Group II if treated with ritodrine.

\section{Treatment protocol}

Group I: Glyceryltrinitrate patch releasing $10 \mathrm{mg} / 24$ hours $(0.4 \mathrm{mg}$ / hour) was transdermally applied to the skin of abdomen below umbilicus. If after an interval of 2 hours there was no reduction in the frequency or duration of contractions an additional patch of $10 \mathrm{mg}$ was applied. Not more than two patches were applied in a day. Patch was left in situ for 24 hours after which it was removed. Assessment of uterine contractions was done every 15 min for the first 2 hours and then at hourly interval for 24 hours. Persistence of contractions even after 48 hours was taken as treatment failure and patient was allowed for delivery. Treatment was discontinued even earlier if any serious side effects were noted.

Group II: Intravenous infusion of Ritodrine was prepared by adding $50 \mathrm{mg}$ to one bottle of $5 \%$ dextrose or ringer lactate solution and infusion started at an initial rate of $0.05 \mathrm{mg} / \mathrm{min}$ which was increased by 50 micrograms per minute every $15 \mathrm{~min}$ until contractions ceased or maternal tachycardia $>140 \mathrm{bpm}$, fetal tachycardia > $180 \mathrm{~min}$ or appearance of sign and symptoms of toxicity like severe hypotension $(<90 \mathrm{mmHg})$, chest pain, shortness of breath etc. Maximum dose given was 350 micrograms per minute. The dose at which the contractions subsided was maintained for 12 hours and then gradually tapered. Oral tablet of $10 \mathrm{mg}$ ritodrine was given 30 min prior to discontinuation of the drip and then one tablet every four hours was continued till 34 completed week.

Antenatal Corticosteroids: All patients were administered Dexamethasone $12 \mathrm{mg}$ intramuscularly in two consecutive doses 12 hours apart.

\section{RESULTS}

Parameters considered for comparison were time and dose required, duration of prolongation of pregnancy, mode of delivery, fetal outcome in terms of birth weight 
and APGAR score. Therapeutic intervention was deemed successful if contractions ceased within 48 hours of initiation of treatment. All patients were discharged after cessation of contractions and assessed antenatally every week as out-patients until delivery. If however contractions failed to subside and/or progressive cervical dilation continued the treatment was labelled as method failure and either a second tocolytic agent was considered or delivery was allowed to occur. At the time of delivery, gestational age, mode of delivery, baby's weight and APGAR score are noted.

\section{Investigations}

Urine analysis for albumin, sugar, microscopy, culture/ sensitivity and Complete Haemogram, Grouping, Rh typing, HIV and HBsAg and USG was done in all cases.

\section{Statistical analysis}

Mean, standard deviation, percentages were determined and presented for each group. Difference between two groups was compared by Mann-Whitney test for continuous data and chi - square test for categorical data. $\mathrm{P}$ value of 0.05 or less was considered for statistical significance.

On admission to Labour Room patients were carefully screened and assigned Groups as per their treatment protocols wherein Group I comprised of patients receiving Transdermal GTN Patch and Group II were given IV Ritrodrine. A total of fifty patients were recruited for the study and 25 patients were randomly assigned to each group.

Table 1: Demographic profile of the patients recruited.

\begin{tabular}{|lllllll|} 
Age & $\begin{array}{l}\text { GTN } \\
\text { (Group I) }\end{array}$ & $\begin{array}{l}\text { Ritodrine } \\
(\text { Group II) }\end{array}$ & $\begin{array}{l}\text { Total } \\
(\mathbf{n = 2 5})\end{array}$ & $\begin{array}{l}\text { (n=25) } \\
\text { (n=50) }\end{array}$ \\
\hline & No. & \% & No. & \% & No. & \% \\
\hline$<\mathbf{2 0}$ & 1 & 4 & 2 & 8 & 3 & 6 \\
\hline $\mathbf{2 0 - 2 5}$ & 19 & 76 & 18 & 72 & 37 & 74 \\
\hline $\mathbf{2 5 - 3 0}$ & 5 & 20 & 5 & 20 & 10 & 20 \\
\hline $\begin{array}{l}\text { Mean } \\
\text { age }\end{array}$ & $23.72 \pm 2.42$ & $23.88 \pm 2.45$ & $23.8 \pm 2.43$ \\
\hline
\end{tabular}

The mean age of both groups were comparable at 23.72 in Group I and 23.88 in Group II, $48 \%$ in both Groups were nulliparous with no statistical difference between both the groups regarding parity.

No statistical significance was noted amongst the two groups with respect to history of previous abortions and preterm deliveries.

Mean cervical effacement was $45 \%$ in Group I (GTN) and $46.33 \%$ in Group II (Ritodrine).
P-value at 0.53 was statistically not significant.

Table 2: Obstetric profile of the patients in both groups.

\begin{tabular}{|c|c|c|c|c|c|c|}
\hline \multirow{3}{*}{$\begin{array}{l}\text { Obstetric } \\
\text { history }\end{array}$} & \multirow{2}{*}{\multicolumn{2}{|c|}{$\begin{array}{l}\text { GTN } \\
(\text { Group I) } \\
(\mathbf{n}=\mathbf{2 5})\end{array}$}} & \multirow{2}{*}{\multicolumn{2}{|c|}{$\begin{array}{l}\text { Ritodrine } \\
\text { (Group II) } \\
(\mathbf{n = 2 5})\end{array}$}} & \multirow{2}{*}{\multicolumn{2}{|c|}{$\begin{array}{l}\text { Total } \\
(\mathbf{n}=\mathbf{5 0})\end{array}$}} \\
\hline & & & & & & \\
\hline & No. & $\%$ & No. & $\%$ & No. & $\%$ \\
\hline $\begin{array}{l}\text { Previous } \\
\text { abortion }\end{array}$ & 5 & 20 & 3 & 12 & 8 & 16 \\
\hline $\begin{array}{l}\text { Previous } \\
\text { preterm } \\
\text { delivery }\end{array}$ & 1 & 4 & 2 & 8 & 3 & 6 \\
\hline
\end{tabular}

Table 3: Therapeutic response to the drugs administered.

\begin{tabular}{|llll|}
\hline Group & $\begin{array}{l}\text { Successful } \\
\text { cases } \\
(\mathrm{n}=25)\end{array}$ & $\begin{array}{l}\text { Failure } \\
\text { cases } \\
(\mathrm{n}=25)\end{array}$ & p-value \\
$\mathbf{n}(\%)$ & $22(88 \%)$ & $3(12 \%)$ & 0.23 \\
\hline $\begin{array}{l}\text { GTN } \\
\text { (Group-I) }\end{array}$ & $19(76 \%)$ & $6(24 \%)$ & \\
\hline $\begin{array}{l}\text { Ritodrine } \\
\text { (Group-II) }\end{array}$ & & \\
\hline
\end{tabular}

Prolongation of gestation by $48 \mathrm{hrs}$ was considered successful tocolysis which was achieved in 41/50 patients (82\%) combined, 22 patients $(88 \%)$ in Group I (GTN) as compared to 19 (76\%) seen in Group II ( IV Ritodrine). P value - 0.23 showed no statistical significance

Table 4: Duration of pregnancy prolongation in successful cases.

\begin{tabular}{|c|c|c|c|c|c|}
\hline \multirow[t]{2}{*}{$\begin{array}{l}\text { Delay in } \\
\text { delivery }\end{array}$} & \multicolumn{2}{|c|}{$\begin{array}{l}\text { GTN }(n=25) \\
(\text { Group-I) }\end{array}$} & \multicolumn{2}{|c|}{$\begin{array}{l}\text { Ritodrine } \\
(n=25) \\
\text { (Group II) }\end{array}$} & \multirow[t]{2}{*}{$\begin{array}{l}p- \\
\text { value }\end{array}$} \\
\hline & No. & $\%$ & No. & $\%$ & \\
\hline $\begin{array}{l}\text { For }>48 \\
\text { hrs }\end{array}$ & 22 & 88 & 19 & 76 & 0.2 \\
\hline $\begin{array}{l}\text { For }>7 \\
\text { days }\end{array}$ & 18 & 72 & 13 & 54 & 0.14 \\
\hline $\begin{array}{l}\text { Till } 37 \\
\text { weeks }\end{array}$ & 11 & 44 & 5 & 20 & 0.07 \\
\hline Median & 70 & & 49 & & 0.04 \\
\hline $\begin{array}{l}\text { Mean } \\
\text { gestational } \\
\text { age } \\
\text { at delivery } \\
\text { (weeks) }\end{array}$ & \multicolumn{2}{|c|}{$34.97 \pm 1.86$} & \multicolumn{2}{|c|}{$33.24 \pm 2.17$} & 0.0004 \\
\hline
\end{tabular}

$88 \%$ patients had pregnancy prolongation by 48 hours, $72 \%$ over a week and $44 \%$ continued over 37 weeks in GTN group compared to $76 \%, 54 \%$, and $20 \%$ in Ritodrine Group. Difference was not statistically significant $(\mathrm{P}=0.07)$. 
Mean Gestational age at delivery was 34.97 in GTN Group as compared to 33.24 weeks in Ritodrine Group which is statistically significant $(\mathrm{P}=0.0004)$

Table 5: Analysis of successful cases.

\begin{tabular}{|c|c|c|c|c|c|}
\hline \multirow[t]{2}{*}{ Parameter } & \multicolumn{2}{|c|}{ GTN (Group I) (n=22) } & \multicolumn{3}{|c|}{ Ritodrine (Group II) $(\mathrm{n}=19)$} \\
\hline & Mean \pm SD & Range & Mean \pm SD & Range & p-value \\
\hline $\begin{array}{l}\text { Time taken (hrs) } \\
\text { to stop contraction }\end{array}$ & $4.84 \pm 2.29$ & $1.5-8.45$ & $7.802 \pm 2.18$ & $4-16.10$ & 0.00002 \\
\hline $\begin{array}{l}\text { Duration (days) of } \\
\text { prolongation of } \\
\text { pregnancy }\end{array}$ & $12.07 \pm 8.03$ & $2-70$ & $7.02 \pm 5.02$ & $2.2-49$ & 0.01 \\
\hline Dose required & $\begin{array}{l}10 \mathrm{mg}-18 \text { Pts } 20 \\
\mathrm{mg}-4 \mathrm{pts}\end{array}$ & $10-20$ & $0.07 \pm 0.06$ & $\begin{array}{l}0.05-3 \\
\mathrm{mg} / \text { minute }\end{array}$ & \\
\hline
\end{tabular}

The mean time taken to inhibit contractions was $4.84 \mathrm{hrs}$ in GTN Group and $7.8 \mathrm{hrs}$ in Ritodrine group. Difference was statistically significant $(\mathrm{p}=0.000020)$

Amongst the successful cases in GTN group 18 patients required one $10 \mathrm{mg}$ patch and 4 patients required 2 patches of $10 \mathrm{mg}$ each $(20 \mathrm{mg})$. The range of dose required for Ritodrine varied from $0.05-0.3 \mathrm{mg} / \mathrm{min}$ with a mean of $0.07 \mathrm{mg} / \mathrm{min}$

Table 6: Comparison of maternal adverse effects of GTN Patch versus IV ritodrine.

\begin{tabular}{|lll|}
\hline Adverse effects & $\begin{array}{l}\text { GTN }(\mathbf{n = 2 5}) \\
(\text { Group-I) }\end{array}$ & $\begin{array}{l}\text { Ritodrine } \\
(\mathbf{n = 2 5}) \\
\text { (Group II) }\end{array}$ \\
\hline Headache & $7(28 \%)$ & 0 \\
\hline $\begin{array}{l}\text { Cutaneous } \\
\text { reaction }\end{array}$ & $4(16 \%)$ & 0 \\
\hline Hypotension & 0 & 0 \\
\hline Dizziness & 0 & $2(8 \%)$ \\
\hline $\begin{array}{l}\text { Tachycardia } \\
(>110 / \text { min })\end{array}$ & 0 & $15(60 \%)$ \\
\hline $\begin{array}{l}\text { Tachycardia } \\
(>140 / \text { min. })\end{array}$ & 0 & $2(8 \%)$ \\
\hline Palpitations & 0 & $5(20 \%)$ \\
\hline $\begin{array}{l}\text { Nausea and } \\
\text { vomiting }\end{array}$ & 0 & $6(24 \%)$ \\
\hline Flushing & 0 & 0 \\
\hline
\end{tabular}

$7(28 \%)$ patients had headache relieved with simple analgesics and few patients had cutaneous reaction in the form of erythematous rash and burning sensation in GTN Group. Comparatively the Ritodrine Group had severe adverse effects requiring discontinuation of therapy in $8 \%$. Tachycardia $>110$ min was seen in $60 \%$ of cases, palpitations in $20 \%$, nausea and vomiting in $24 \%$ and dizziness in $8 \%$ but serious adverse effects like Pulmonary edema and hypotension was not observed.
Table 7: Comparison of Neonatal adverse effects in successful cases.

\begin{tabular}{|lllll|}
\hline $\begin{array}{l}\text { Neonatal adverse } \\
\text { effects }\end{array}$ & \multicolumn{2}{l}{$\begin{array}{l}\text { GTN (n=22) } \\
\text { Group I) }\end{array}$} & $\begin{array}{l}\text { Ritodrine } \\
(\mathbf{n = 1 9 )} \\
\text { (Group II) }\end{array}$ \\
\cline { 2 - 5 } & No. & $\%$ & No. & \% \\
\hline Hypothermia & 2 & 9.09 & 3 & 15.78 \\
\hline Hypoglycaemia & 1 & 4.5 & 2 & 10.52 \\
\hline Hyperbilirubinemia & 1 & 4.5 & 6 & 31.58 \\
\hline Hypocalcemia & 0 & 0 & 2 & 10.52 \\
\hline $\begin{array}{l}\text { Respiratory } \\
\text { Distress Syndrome }\end{array}$ & 0 & 0 & 3 & 15.78 \\
\hline Sepsis & 0 & 0 & 6 & 31.58 \\
\hline
\end{tabular}

No case of fetal distress was detected in in GTN Group as compared to $4(16 \%)$ in Ritodrine. There was no case of Intra uterine death or Stillbirth in either groups.

Birth weight in GTN Group was found to be better with 10 neonates having Birth Weight $>2.5 \mathrm{~kg}$ as compared to only 2 in Ritodrine Group. Mean Birth Weight was higher in GTN Group (2.36kg versus $2.05 \mathrm{~kg}$ ) as compared to Ritodrine Group.

\section{DISCUSSION}

Tocolysis should not be attempted if the patient is in advanced labour as the risk of Intra uterine infection, placental abruption increases. ${ }^{18} \mathrm{~A}$ search for an alternative agent to Beta Adrenergic Agonist Ritodrine and Terbutaline with better efficiency and minimal sideeffects led to considerable interest in Nitric oxide donors, used in the form of transdermal Glyceryl Trinitrite Patch, as a safer alternative for tocolysis. ${ }^{19}$

Mean Absolute prolongation of gestation was not statistically significant in both the studies. 
Table 8: Neonatal outcome.

\begin{tabular}{|lll|}
\hline Weight (kgs) & $\begin{array}{l}\text { GTN (n=22) } \\
\text { (Group I) }\end{array}$ & $\begin{array}{l}\text { Ritodrine } \\
\text { (n=19) } \\
\text { (Group II) }\end{array}$ \\
\hline$<1.5$ & 0 & 3 \\
\hline $1.5-2.0$ & 1 & 4 \\
\hline $2.0-2.5$ & 11 & 10 \\
\hline$>2.5$ & 10 & 2 \\
\hline APGAR score & & 0 \\
\hline $\begin{array}{l}\text { 0-3 (severely } \\
\text { asphyxiated) }\end{array}$ & 0 & 0 \\
\hline $\begin{array}{l}\text { 4-6 (moderately } \\
\text { asphyxiated) }\end{array}$ & 0 & 19 \\
\hline $\begin{array}{l}\text { 7-10 (non } \\
\text { asphyxiated) }\end{array}$ & 22 & 12 \\
\hline NICU admission & & 12 \\
\hline No. of Admission & 4 & 12 \\
\hline \begin{tabular}{l} 
Cause of admission \\
\hline Prematurity
\end{tabular} & 4 & \\
\hline $\begin{array}{l}\text { Meconium } \\
\text { aspiration }\end{array}$ & 0 & \\
\hline \begin{tabular}{l} 
Birth asphyxia \\
\hline
\end{tabular} & 0 & \\
\hline
\end{tabular}

GTN Group showed higher success rate as compared to Ritodrine group ( $88 \%$ versus $76 \%, \mathrm{p}=0.23$ ) as opposed to study conducted by Lees et al (1999) ${ }^{20}$ who showed that Ritodrine may be more effective ( $84 \%$ vs $90 \%$ for GTN and Ritodrine). Both the present study and Lees et al concluded that both drugs were equally effective in prolongation of gestation which was 12 days for GTN Patch and 7days with Ritodrine as compared to 35.8 days and 36.9 days reported by Lees et al. ${ }^{20}$ The difference was not statistically significant.

Other than headache and cutaneous reaction at the site of application, no serious adverse effects like maternal hypotension, giddiness etc. was noted with GTN Patch in the present study. Rowlands et $\mathrm{al}^{21}$, Lees et al ${ }^{20}$ reported $3.12 \%$ and $3 \%$ cases complaining of giddiness and Lees et al reported $7.69 \%$ patients developing hypotension for which the patch had to be removed. Ritodrine, a nonselective, beta adrenergic receptor stimulator may act on beta receptors of the heart thus producing significant maternal adverse effects like tachycardia, atrial flutter, insufficiencies, arrhythmias and ischemia. ${ }^{15,18}$ Metabolic abnormalities, electrolyte imbalance and Pulmonary edema (5\%) may result in life threatening complications and maternal mortality. ${ }^{22}$ No patient in both groups had side effects severe enough to warrant stoppage of the treatment.

Transdermal Glyceryltrinitrate can become a safe alternative to Ritodrine as a uterine tocolytic considering its excellent safety record and insignificant adverse effects at the low doses administered for suppression of preterm labour as opposed to Beta Agonists which shows reduced tocolytic efficacy with time and high susceptibility to tachyphylaxis, headache and other side effects particularly associated with beta agonist. ${ }^{23}$

The low cost, ease of administration and early ambulation of the patient are few of the other advantages of Glyceryltrinitrate over Ritodrine. However further controlled trails to study possible neonatal outcome is recommended.

Informed consent was obtained from all individual participants included in the study.

\section{CONCLUSION}

Glyceryl trinitrate and Ritodrine are both effective tocolytics without risk of serious complications. Glyceryl trinitrate appears to be a very viable, inexpensive and safer alternative to the traditionally used beta agonist Ritodrine, especially for such women who require transfer for neonatal care or time to complete a course of steroids tocolytics. Thus, further studies with larger sample size are needed to evaluate the exact effects of glyceryl trinitrate on preterm labor.

\section{Funding: No funding sources}

Conflict of interest: None declared

Ethical approval: The study was approved by the Institutional Ethics Committee

\section{REFERENCES}

1. Saigal S, Doyle LW. An overview of mortality and sequelae of preterm birth from infancy to adulthood. Lancet. 2008;371:261-9.

2. Cunningham F Leveno K, Bloom S, Hauth J, Rouse D, Spong C. Williams; Obstetrics $23^{\text {rd }}$ ed. New York: McGraw Hill; 2009. pp. 804-32.

3. Enkin M, Keirse MJNC, Neilson J, Crowther C, Duley LMM, Hodnett E, et al. Guide to Effective Care in Pregnancy and Childbirth. 3rd ed. Oxford: Oxford University Press; 2000.

4. Slattery MM, Morrison JJ. Preterm Delivery. Lancet. 2002;360:1489-97.

5. Dhawle A, Kalra J. Nifedipine versus nitroglycerin for acute tocolysis in preterm labour: a randomised controlled trial. Int $\mathbf{J}$ Reprod Contracept Obstet Gynecol. 2013;2(1):61-6.

6. Moser K, Macfarlane A, Chow YH, Hilder L, Dattani N. Introducing new data on gestationspecific infant mortality among babies born in 2005 in England and Wales. Health Stat Q. 2007:13-27.

7. Kramer MS, Demissie K, Yang H, Platt RW, Sauvé $\mathrm{R}$, Liston $\mathrm{R}$, et al. The contribution of mild and moderate preterm birth to infant mortality. JAMA. 2000;284:843-9.

8. Chandraharan E, Arunkumaran S. Recent advances in management of preterm labour. J Obstet Gynec India. 2005;55:118-24. 
9. Hack M, Taylor HG, Klein N. School-age outcomes in children with birth weight under $750 \mathrm{~g}$. N Engl J Med. 1994;331:753-9.

10. Cunningham FG, Gant NF, Leveno KS, Gilstrop LC, Hautt JC, Werstrom KD, Editors. Preterm Birth, in Williams obstetrics: 21st ed, New York: McGrawHill, 2001 p.689-727.

11. Usharani N, Lakshmi K. To know the efficacy of Glyceryl Trinitratate Patch and Ritodrine as tocolytic agents: A comparative study. Journal of Evidence based Medicine and Healthcare. 2015;2(7):818-25.

12. Haas DM. Tocolytic therapy for preterm delivery: systematic review and network meta-analysis. BMJ. 2012;345:e6226.

13. Roberts D, Dalziel SR. Antenatal corticosteroids for accelerating fetal lung maturation for women at risk of preterm birth. Cochrane Database Syst Rev. 2006;(3):CD004454.

14. Barden TP, Peter JB, Merkatz IR. Ritodrine Hydrochloride: A Betamimetic agent for use in preterm labour. Obstet Gynecol. 1980;56(1):1-7.

15. Dollery C. Ritodrine (hydrochloride). In: Therapeutic drugs. 2ndedn. Vol 2, Edinburgh: Churchill Livingstone, 1999. pp. R47-R49.
16. Duckitt K, Thornton S. Nitric oxide donors for the treatment of preterm labour. Cochrane Database of Systematic Reviews 2002;3. Art. No.: CD002860.

17. Katzung B. Basic and clinical pharmacology: Lange Medical Books. 11th ed. London: McGraw Hill; 2001. pp. 93-6.

18. RCOG: Clinical Guideline No. 1(B) October 2002; Page 1-7.

19. RCOG : Green Top Guideline No. 1b February 2011; Page 1-13.

20. Lees CC, Lojacono A, Thompson C, Danti L, Black RS, Tanzi P, et al. Glyceryl Trinitrate and Ritodrine in Tocolysis An International Multicenter Randomized Study. 1999;94(3):403-8.

21. Rowlands S, Trudinger B, Visvalingam S. Treatment of preterm cervical dilatation with Glyceryl Trinitrate, a Nitric acid donor. Aust NZ Obstet Gynecol. 1996;36(4):377-81.

22. Dollery C. Nitroglycerin In: Therapeutic drugs: $2^{\text {nd }}$ edn. Vol 2, Edinburg: Churchill Livingstone, 1999. pp. N117-N120.

Cite this article as: Jain C, Sinha M, Rani R, Tiwari A. Glyceryl trinitrate patch versus intravenous ritodrine for tocolysis in pre-term labour. Int $\mathbf{J}$ Reprod Contracept Obstet Gynecol 2016;5:4447-52. 